\title{
DAMPAK DIKLAT TERHADAP LITERASI INFORMASI PESERTA DIKLAT
}

\author{
Epa Elfitriadi \\ Badan Penelitian dan Pengembangan dan Pendidikan dan Pelatihan - Kementerian Agama \\ Email: elfitriadi@gmail.com \\ https://doi.org/10.36052/andragogi.v7i2.102 \\ Diterima: 24 Oktober 2019 | Disetujui: 3 Desember 2019 | Dipublikasikan: 30 Desember 2019
}

\begin{abstract}
Abstrak
Tujuan penelitian ini untuk mengetahui tingkat literasi informasi peserta diklat sebelum dan sesudah mengikuti diklat serta tingkat signifikansi pengaruh diklat terhadap kemampuan literasi informasi peserta. Metode survei digunakan pada sampel 30 orang peserta Diklat Teknis Substantif Publikasi IImiah. Instrumen kuesioner berskala likert dikonstruk dari tiga aspek model Empowering-8, yaitu identifikasi, organisasi dan membuat/menciptakan. Hasil penelitian menunjukkan bahwa rerata skor tingkat literasi informasi peserta di awal diklat termasuk kategori "baik" hanya pada aspek kemampuan organisasi sedangkan aspek kemampuan identifikasi dan aspek kemampuan membuat/menciptakan serta secara global termasuk kategori "kurang/rendah". Kemudian setelah mengikuti diklat, skor tersebut meningkat menjadi "baik" pada ketiga aspek, yaitu aspek kemampuan identifikasi, aspek kemampuan organsiasi dan aspek kemampuan membuat/menciptakan. Hasil uji-t pada tingkat kepercayaan 95\% diperoleh nilai Sig-2 tailed $=0,00<0,05$, menunjukkan adanya perbedaan yang signifikan antara kemampuan literasi informasi peserta diklat sebelum dan sesudah mengikuti diklat. Hasil ini membuktikan bahwa diklat berpengaruh terhadap peningkatan tingkat literasi informasi peserta diklat.
\end{abstract}

Kata Kunci: literasi informasi, model empowering-8, diklat

\begin{abstract}
This research aims to examine the information literacy of training participants before and after training and also the significance level of the effect of education and training on the participant information literacy. The survey method was used on 30 participants of Substantive Technical Training in Scientific Publications. The Likert scale questionnaire instrument was constructed from three aspects of the Empowering-8 model, namely identification, organization and making / creating. The results showed that the average score of information literacy level of participants at the beginning of the training included the "good" category only in the aspect of organizational capability while the aspect of identification ability and the ability to create / create as well as globally included the "less / low" category. Then the score increased to "good" in those aspects. $T$-test results at a 95\% confidence level obtained by the Sig-2 tailed value $=0.00<0.05$. It proves that there is a significant difference between the information literacy of the training participants before and after training. These results prove that training have an effect on increasing the level of information literacy of training participants..
\end{abstract}

Keywords: information literacy, empowering-8 model, training 


\section{PENDAHULUAN}

$I$ Imu pengetahuan dan teknologi yang berkembang pesat dan dinamis telah mengantarkan manusia ke era digital. Era ini ditandai oleh tumbuh kembangnya teknologi digital yang menyentuh hampir seluruh aspek kehidupan manusia. Era digital telah membuat dunia menjadi tanpa batas. Banyak hal dalam kehidupan manusia saat ini serba digital dan saling terhubung tanpa terbatasi ruang dan waktu.

Dalam sistem informasi yang terbuka dan hampir tanpa batas ini, ledakan informasi tak dapat terelakan lagi. Jumlah informasi sangat melimpah dan beragam. Kondisi ini membuat banyak pihak semakin menyadari bahwa kecakapan dalam memperoleh, memilih dan mengelola secara selektif informasi yang dibutuhkan merupakan faktor yang sangat penting selain akses terhadap informasi itu sendiri (Husaebah Pattah, 2014). Kecakapan tersebut didalamnya menuntut kompetensi yang sejalan dengan perkembangan teknologi informasi dan komunikasi (TIK). Kecakapan inilah yang kemudian dihubungkan dengan istilah literasi informasi.

Literasi informasi menurut Association of College and Research Libraries (ACRL) dan UNESCO merupakan kerangka intelektual seseorang untuk memahami, mengidentifikasi, menemukan, mengevaluasi, mengelola, menggunakan dan mengomunikasikan informasi sesuai kebutuhannya sebagai bagian dari hak asasi manusia dalam pembelajaran seumur hidup (Fajarwati, 2012; Mirazita \& Rohmiyati, 2015; Permata Ganggi, 2017).
Dalam lingkup dunia pendidikan, kecakapan literasi menjadi penting dimiliki peserta didik maupun guru. Literasi akan membantu peserta didik dalam memahami informasi teks, audio maupun visual dan membantu mereka dalam mencapai prestasi belajarnya. Hal ini sebagaimana hasil penelitian Fajarwati (2012) dan Muhajang \& Pangestika (2018) yang menyimpulkan bahwa kemampuan literasi informasi peserta didik yang baik berpengaruh linear terhadap prestasi belajarnya.

Literasi juga sangat diperlukan guru sebagai role model bagi peserta didik agar mampu meng-update informasi, mengakses, memahami kemudian menggunakannya dalam proses pembelajaran. Guru yang cakap literasi akan menunjang kecakapan literasi peserta didik (Marwan, 2017).

Namun demikian, realita dunia pendidikan Indonesia menunjukkan bahwa tingkat literasi Indonesia masih belum memuaskan. Hal ini sebagaimana ditunjukkan hasil riset Programme for International Students Asessment (PISA) yang digagas oleh OECD (Organization for Economic Cooperation and Development). PISA mengevaluasi sistem pendidikan dari puluhan negara di seluruh dunia dengan membuat peringkat terkait kemampuan dan pengetahuan siswa kisaran usia 15 tahun dalam literasi membaca, matematika dan sains yang diperlukan agar dapat berpartisipasi penuh dalam kehidupan masyarakat modern. PISA berasumsi bahwa kesuksesan di bidang ekonomi modern bukan terletak pada apa yang seseorang ketahui tetapi apa yang dapat seseorang lakukan dengan apa 
yang diketahuinya. Menurut hasil riset PISA 2015, peringkat peserta didik Indonesia masih berada di posisi bawah yaitu peringkat ke 62 dari 72 negara, meski keadaan ini meningkat dari posisi ke 71 pada dua tahun sebelumnya (Pellini, 2016 dan Sidharta, 2017).

Lebih khusus menurut UNESCO tingkat literasi membaca di Indonesia masih relatif rendah dengan perbandingan dari 1000 orang hanya 1 orang yang memiliki minat baca tinggi. Dari total 61 negara, Indonesia berada di peringkat 60 dengan tingkat literasi rendah

(https://student.cnnindonesia.com). Hal ini ditambah lagi sejumlah data Badan Pusat Statistika yang menunjukkan tingkat buta aksara latin penduduk Indonesia kelompok usia 15 tahun ke atas masih tergolong relatif tinggi (https://bps.go.id).

Rendahnya tingkat kompetensi literasi tersebut menjadi potret kegelisahan dunia pendidikan di Indonesia. Sebab, kompetensi literasi peserta didik menjadi salah satu indikator keberhasilan proses pendidikan.

Dalam hal ini guru merupakan pihak yang berperan sebagai mediator dan fasilitator dalam proses kontruksi pengetahuan dan keterampilan peserta didik, termasuk kompetensi literasinya. Kreativitas guru dalam merancang kegiatan pembelajaran akan berdampak pada peningkatan kemampuan berpikir peserta didik. Karena, pada dasarnya kemampuan berpikir kreatif peserta didik adalah produk dari proses kreatif guru itu sendiri. Penelitian Latifah \& Husna (2016), Fauziah (2015), Marwan (2017), dan Anggraeni \& Rola (2018) memperkuat pandangan tersebut, bahwa guru memiliki kontribusi yang sangat penting dalam membangun literasi informasi pembelajarnya.

Oleh karena itu pengembangan kompetensi literasi informasi para guru sangat diperlukan dalam rangka meningkatkan kecakapan literasi informasi peserta didik. Satu di antara beberapa cara pengembangan kompetensi guru dan pegawai pada umumnya adalah dilakukan melalui program pendidikan dan pelatihan (diklat).

Diklat dilihat dalam konteks kepentingan organisasi memiliki pengertian yang sama dengan training, sebagaimana disebutkan oleh beberapa ahli. Franco dalam Wahyuningsih (2012) berpandangan bahwa training bertujuan mengubah kinerja seseorang dalam bekerja. Sastradipoera dalam Jayanthi \& Cahyana (2014) mendefinisikan training adalah suatu proses pendidikan jangka pendek yang menggunakan prosedur yang sistematik dan terorganisasi yang dengan prosedur itu personalia nonmenejerial belajar pengetahuan dan keterampilan teknis untuk mencapai tujuan tertentu.

Berdasarkan hal tersebut dapat dipahami bahwa training atau diklat merupakan kegiatan pembelajaran yang terencana untuk meningkatkan pengetahuan dan keterampilan agar kinerja individu dan organisasi meningkat.

Salah satu diklat bagi guru yang diselenggarakan Pusdiklat Tenaga Teknis Pendidikan dan Keagamaan (selanjutnya disebut Pusdiklat Teknis) sebagai institusi yang berwenang dalam penyelenggaraan diklat di Kementerian Agama adalah Diklat Teknis Substantif (DTS) Publikasi Ilmiah bagi Guru Madrasah. DTS Publikasi Ilmiah 
diselenggarakan dalam 60 jam pelatihan (JP) dengan komposisi teori 26 JP dan praktik 34 JP. Kurikulumnya terbagi dalam tiga bagian yaitu: kelompok dasar (9 JP) dan kelompok penunjuang (8 JP) untuk membekali peserta dengan wawasan umum kediklatan, regulasi dan kebijakan peningkatan sumber daya manusia di lingkungan Kementerian Agama; serta kelompok inti (43 JP) untuk meningkatkan kompetensi peserta dalam bidang karya tulis ilmiah guru yang dipublikasikan (publikasi ilmiah guru). Kelompok inti terdiri dari 5 (lima) mata diklat, yaitu: (1) konsep dasar publikasi ilmiah, (2) publikasi ilmiah bentuk laporan hasil penelitian, (3) publikasi ilmiah bentuk makalah tinjauan ilmiah, (4) publikasi ilmiah bentuk buku,dan (5) publikasi ilmiah bentuk tulisan ilmiah populer (Pusdiklat Tenaga Teknis Pendidikan dan Keagamaan, 2018).

DTS Publikasi Ilmiah yang diselenggarakan Pusdiklat Teknis ini secara normatif berdampak pada peningkatan kompetensi bidang karya tulis ilmiah guru. Namun, apakah keikutsertaan guru dalam diklat ini berdampak juga pada peningkatan kecakapan literasi informasi mereka? Berdasarkan hasil penelusuran referensi, belum ditemukan adanya penelitian khusus terkait hal tersebut. Adapun penelitian (Solihat, Johan, \& Rosinar, 2014) relatif berbeda kasusnya karena penelitiannya berfokus pada kontribusi literasi informasi terhadap proses penulisan karya ilmiah.

Banyak ahli telah merumuskan strategi untuk mengetahui kemampuan literasi informasi seseorang, yang kemudian disebut model literasi informasi. Ada berbagai model literasi informasi yang biasa digunakan di dunia kerja diantaranya Big6, Empowering-8, Seven Pillars, dan Information Search Process (ISP) (Suntoro, 2019). Penelitian ini menggunakan model Empowering-8.

Model literasi informasi Empowering-8 dihasilkan dari workshop yang diselenggarakan di Srilangka tahun 2004 dan di India tahun 2005 dengan melibatkan peserta dari 10 negara Asia Selatan dan Asia Tenggara. Model Empowering-8 dapat dipergunakan untuk memecahkan berbagai persoalan terkait informasi melalui delapan tahapan sebagiamana ditunjukkan dalam Gambar 1 dan Tabel 1. Delapan tahapan menggambarkan siklus yang saling berkaitan dan berulang serta dapat dimulai dari titik/tahapan mana saja (Mirazita \& Rohmiyati, 2015).

Tabel 1. Deskripsi unsur dalam Model Empowering-8

\begin{tabular}{ccl}
\hline Langkah & Komponen & \multicolumn{1}{c}{ Hasil yang didemonstrasikan } \\
\hline 1 & Mengidentifikasi & - Mendefinisikan topik/subjek \\
& & - Menentukan dan memahami sasaran penyajian \\
& & Memilih format yang relevan untuk produk \\
& & ahir \\
& & Mengidentifikasi berbagai jenis sumber \\
& & informasi \\
\hline 2 & Mengeksplorasi & - Menentukan lokasi sumber yang sesuai topik \\
& & - \\
& & Menemukan informasi yang sesuai dengan \\
& & topik
\end{tabular}




\begin{tabular}{|c|c|c|}
\hline & & $\begin{array}{l}\text { - Melakukan wawancara, kunjungan lapangan } \\
\text { atau penelitian lain }\end{array}$ \\
\hline 3 & Menyeleksi & $\begin{array}{l}\text { - Memilih informasi yang relevan } \\
\text { - Menentukan sumber mana saja yang terlalu } \\
\text { mudah, terlalu sukar atau sesuai } \\
\text { - Mencatat informasi yang relevan dalam bentuk } \\
\text { catatan atau visual seperti chart, grafik, bagan } \\
\text { dll } \\
\text { - Mengidentifikasi tahap-tahap dalam proses } \\
\text { - Mengumpulkan sitiran yang sesuai }\end{array}$ \\
\hline 4 & Mengorganisasi & $\begin{array}{l}\text { - Menyortir informasi } \\
\text { - Membedakan antara fakta, opini dan fiksi } \\
\text { - Memeriksa ada tidaknya bias dalam sumber } \\
\text { - Menggunakan pengorganisasi visual untuk } \\
\text { membandingkan atau membuat kontras } \\
\text { informasi yang diperoleh }\end{array}$ \\
\hline 5 & Menciptakan & $\begin{array}{l}\text { - Menyiapkan informasi menggunakan bahasa } \\
\text { sendiri } \\
\text { - Merevisi atau mengedit (sendiri maupun } \\
\text { dengan teman atau pembimbing) } \\
\text { - Menyelesaikan format bibliografi/daftar } \\
\text { pustaka }\end{array}$ \\
\hline 6 & Mempresentasikan & $\begin{array}{l}\text { - } \text { Berbagi informasi dengan orang atau } \\
\text { pendengar yang sesuai } \\
\text { - } \text { Menyajikan informasi dalam format yang tepat } \\
\text { - Menyiapkan dan menggunakan peralatan yang } \\
\text { sesuai }\end{array}$ \\
\hline 7 & Menilai & $\begin{array}{l}\text { - Menerima masukan dari pendengar } \\
\text { - Menilai kinerja pribadi sebagai tanggapan atas } \\
\text { penilaian dari pihak lain } \\
\text { - Merefleksi seberapa baiknya informasi hasil } \\
\text { penelusuran yang telah dilakukan } \\
\text { - Menentukan belajar dengan keterampilan baru } \\
\text { yang diperoleh } \\
\text { - Mempertimbangkan apa yang dapat dilakukan } \\
\text { dengan lebih baik di waktu mendatang }\end{array}$ \\
\hline 8 & Menerapkan & $\begin{array}{l}\text { - Meninjau masukan serta penilaian yang } \\
\text { diberikan } \\
\text { - Menggunakan masukan serta penilaian untuk } \\
\text { keperluan aktivitas berikutnya } \\
\text { - } \text { Menggunakan pengetahuan yang baru } \\
\text { diperoleh dalam berbagai situasi } \\
\text { - Menentukan subyek lain yang dapat dilakukan } \\
\text { penerapan keterampilan yang diperoleh } \\
\text { - Memberi tambahan pada portofolio yang } \\
\text { dibuat }\end{array}$ \\
\hline
\end{tabular}

\begin{tabular}{lllr}
\hline Berdasarkan & hal tersebut, & Publikasi Ilmiah Guru Madrasah dan \\
penelitian ini bertujuan untuk & sejauh mana diklat tersebut \\
mengetahui tingkat literasi informasi & berpengaruh terhadap peningkatan \\
peserta Diklat Teknis Substantif & literasi informasi peserta.
\end{tabular}




\section{METODE PENELITIAN}

Penelitian ini menggunakan pendekatan kuantitatif dengan metode survei. Penelitian dilaksanakan pada kegiatan Diklat Teknis Substantif (DTS) Publikasi Ilmiah saat IJT (in the job training) yang dilaksanakan tanggal 814 April 2019 di Kampus Pusdiklat Tenaga Teknis Pendidikan dan Keagamaan Jl. Ir. H. Juanda No. 37 Ciputat Kota Tangerang Selatan Provinsi Banten.

Sampel penelitian berjumlah 30 orang guru mata pelajaran di Madrasah Tsanawiyah (MTs) utusan dari Kanwil Kementerian Agama Provinsi seIndonesia yang menjadi peserta DTS Publikasi Ilmiah.

Teknik pengumpulan data menggunakan instrumen angket/ kuesioner tertutup berbentuk skala likert dengan 4 (empat) pilihan jawaban untuk setiap item sebagai berikut.

Tabel 2. Skala jawaban kuesioner

\begin{tabular}{clc}
\hline No & Alternatif Jawaban & Bobot \\
\hline 1 & Sangat Tidak Setuju & 1 \\
& (STS) & \\
2 & Tidak Setuju (TS) & 2 \\
3 & Setuju (S) & 3 \\
4 & Sangat Setuju (SS) & 4 \\
\hline
\end{tabular}

Instrumen angket/kuesioner sebagai alat ukur kemampuan literasi informasi dibangun berdasarkan 3 (tiga) tahapan/aspek dalam model Empowering-8. Tiga tahapan/aspek ini selanjutnya ditetapkan sebagai dimensi/variabel penelitian yaitu Identifikasi (X1), Organisasi (X2) dan Membuat/menciptakan sebagaimana Tabel 3 di bawah. Selanjutnya dimensi/variabel penelitian diuraikan menjadi butir-butir pernyataan.
Dengan instrumen tersebut penelitian ini terbatas pada kajian yang berbasis persepsi sikap guru dan belum dapat menggambarkan pengetahuan kognitif tentang literasi informasi.

Tabel 3. Kisi-kisi instrumen

\begin{tabular}{cl}
\hline No & Dimensi dan Indikator Instrumen \\
\hline 1 & Mengidentifikasi (X1) \\
- & Mendefinisikan topik/subjek \\
- & Menentukan dan memahami \\
& sasaran penyajian \\
- & Memahami kaidah dan format yang \\
& relevan \\
- & Menentukan lokasi sumber yang \\
& sesuai topik \\
- & Mengidentifikasi berbagai jenis \\
& sumber informasi \\
- & Menemukan informasi yang sesuai \\
& dengan topik \\
\hline 2 Mengorganisasi (X2) \\
- Menyortir informasi \\
- Membedakan antara fakta, opini \\
dan fiksi \\
- Memeriksa ada tidaknya bias dalam \\
sumber \\
- Menggunakan pengorganisasi \\
visual untuk membandingkan atau \\
membuat kontras informasi yang \\
diperoleh \\
\hline 3 Membuat/Menciptakan (X3) \\
- Menyiapkan informasi \\
menggunakan bahasa sendiri \\
- Merevisi atau mengedit (sendiri \\
maupun dengan teman atau \\
pembimbing) \\
- Menyelesaikan format \\
bibliografi/daftar pustaka \\
\hline
\end{tabular}

Pembatasan hanya pada tiga dimensi/aspek ini dikarenakan penelitian dilakukan pada saat IJT (in the job training) yang tidak menuntut hasil akhir produk peserta. Hasil produk peserta disusun, dipresentasikan dan dinilai pasca diklat IJT yaitu pada saat OJT (on the job training) sehingga model Empowering-8 untuk tahapan/aspek mempresentasikan, 
menilai, dan menerapkan tidak digunakan di saat IJT.

Untuk mengetahui pengaruh diklat terhadap kemampuan literasi informasi peserta, instrumen disebarkan kepada responden dalam dua tahap. Yakni, tahap "Sebelum", dilakukan di awal diklat sebelum penyampaian mata diklat kelompok inti yaitu di tanggal 9 April 2019, dan tahap "Sesudah", dilakukan setelah penyampaian seluruh mata diklat kelompok inti di tanggal 13 April 2019.

Data yang telah dikumpulkan kemudian diolah dan dianalisis menggunakan aplikasi SPSS dan Microsoft Excel. Metode analisis data yang digunakan adalah analisis deskriptif dan uji-t. Analisis deskriptif dilakukan dengan melihat ukuran pemusatan data dan proporsi pada masing-masing komponen. Rangkuman informasi sebaran data ditampilkan secara visual menggunakan grafik Box and Whisker Plots atau disebut BoxPlot. Sedangkan untuk mengetahui signifikansi perbedaan kompetensi literasi peserta sebelum dan sesudah diklat digunakan uji komparatif t-test sampel berpasangan (paired sample ttest) pada tingkat kepercayaan 95\%.

Hipotesis uji pengaruh diklat terhadap literasi informasi dalam penelitian ini adalah

$\mathrm{H}_{0}$ : Tidak ada perbedaan kompetensi literasi informasi peserta diklat antara sebelum dan sesudah penyampaian materi diklat inti

$\mathrm{H}_{1}$ : Ada perbedaan kompetensi literasi informasi peserta diklat antara sebelum dan sesudah penyampaian materi diklat inti.

Perbedaan tingkat kompetensi literasi sebelum dan sesudah diklat dideskripsikan berdasarkan interpretasi terhadap skala interval setiap variabel/aspeknya. Dengan 4 (empat) pilihan jawaban kuesioner, skor jawaban responden terrendah adalah 1 dan tertinggi adalah 4 maka diperoleh interval kelas (4-1):4=0,75, sehingga diperoleh interpretasi terhadap skor/nilai mean variabel sebagai berikut:

Tabel 4. Skor dan Kategori

\begin{tabular}{ccl}
\hline No & Skor & Kategori \\
\hline 1 & $1,00-1,75$ & Sangat \\
& & kurang \\
2 & $1,76-2,51$ & Kurang \\
3 & $2,52-3,27$ & Baik \\
4 & $3,28-4,03$ & Sangat baik \\
\hline
\end{tabular}

\section{TEMUAN DAN PEMBAHASAN}

\section{Karakteristik Responden}

Subjek penelitian ini adalah 30 orang peserta DTS Publikasi Ilmiah yang terdiri dari para guru MTs utusan dari Kanwil Kementerian Agama provinsi seIndonesia. Karakteristik 30 orang responden terlihat pada Gambar 1 berikut.

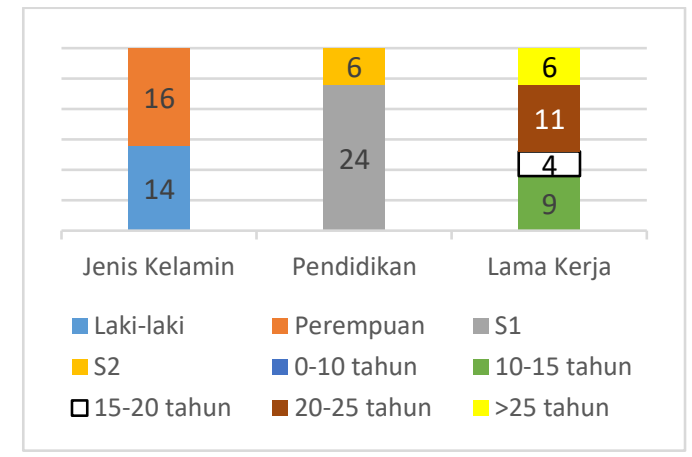

Gambar 1. Komposisi sampel berdasarkan jenis kelamin, pendidikan dan lama kerja

Terlihat dari Gambar 1 di atas, responden terdiri dari 14 orang laki-laki dan 16 orang perempuan. Dari segi latar belakang pendidikan, mayoritas responden berpendidikan S1 yaitu 
sebanyak 24 orang, sedangkan sisanya sebanyak 6 orang berpendidikan S2. Dililhat dari masa bekerjanya, sebanyak 9 orang telah bekerja selama 10-15 tahun, 4 orang selama 15-20 tahun, 11 orang selama 20-25 tahun dan 6 orang di atas 25 tahun.

Jadi secara umum kualifikasi responden cukup memadai karena berlatar belakang sarjana dan berpengalaman kerja lebih dari 15 tahun. Masa kerja tersebut berkorelasi signifikan dengan kinerja. Artinya pengalaman kerja menjadi salah satu faktor yang mendukung peningkatan kinerja. Seorang guru yang memiliki pengalaman kerja cukup lama cenderung semakin baik kinerja dan profesionalismenya dalam menjalankan tugas sebagai guru (Sudarsono, 2011). Peningkatan kinerja tentu terkait erat dengan kecakapan literasi informasi yang dimilikinya.

\section{Analisis Data Kondisi Sebelum dan Sesudah Diklat}

Data yang diperoleh dari penelitian ini berupa jawaban responden atas instrumen penelitian (kuesioner), terdiri dari dua macam yaitu data sebelum dan data sesudah penyampaian seluruh mata diklat pada kelompok materi inti.

Berdasarkan data jawaban responden pada kondisi Sebelum diklat yang ditampilkan melalui Gambar 2, tampak bahwa sebanyak 53,51\% responden menjawab "Sangat Tidak Setuju" (12,63\%) dan "Tidak Setuju" (40,88\%). Hal ini merupakan akumulasi jawaban "Tidak Setuju" dan "Sangat Tidak Setuju" dari ketiga variabel/aspek literasi informasi yaitu aspek kemampuan Identifikasi sebanyak 64,28\%, aspek kemampuan Organisasi sebanyak 28,33\% dan kemampuan Membuat/menciptakan sebanyak $66,14 \%$. Sedangkan untuk aspek kemampuan Organisasi didominasi oleh jawaban "Setuju" (54,44\%) dan "Sangat Setuju" (17,22\%). Jumlah ini lebih banyak daripada aspek lainnya.

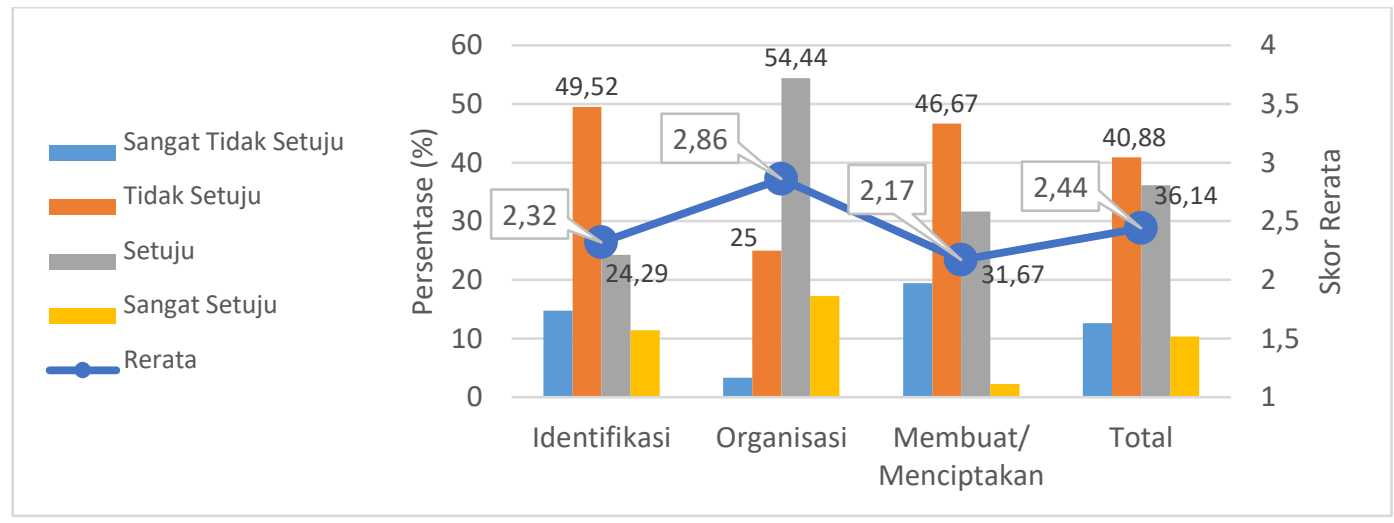

Gambar 2. Sebaran persentase dan rerata data Sebelum diklat

Jika melihat skor rerata, hanya aspek kemampuan Organisasi dengan skor 2,82 yang termasuk kategori "Baik", sedangkan aspek kemampuan Identifikasi (skor 2,32) dan Membuat/menciptakan (skor 2,17) tergolong kategori "Kurang". Maka, secara total rerata dari ketiga aspek kemampuan tersebut dengan skor 2,44 tergolong kategori "Kurang". 
Berdasarkan hal tersebut dapat dikatakan bahwa di awal diklat sebagian besar responden sebanyak 53,51\% mempersepsikan tingkat literasi informasi dirinya termasuk ke dalam kategori kurang/rendah. Selanjutnya kondisi ini berubah setelah mereka mengikuti diklat.

Sebaran jawaban pada kondisi Sesudah diklat sebagaimana pada
Gambar 3, terlihat sebanyak $66,67 \%$ responden lebih banyak menjawab "Setuju" (47,37\%) dan "Sangat Setuju" (19,30\%). Hal ini sebagai akumulasi jawaban "Setuju" dan "Sangat Setuju" dari aspek kemampuan Identifikasi (50,23\%), kemampuan Organisasi (83,89\%) dan kemampuan Membuat/ menciptakan (62,78\%).

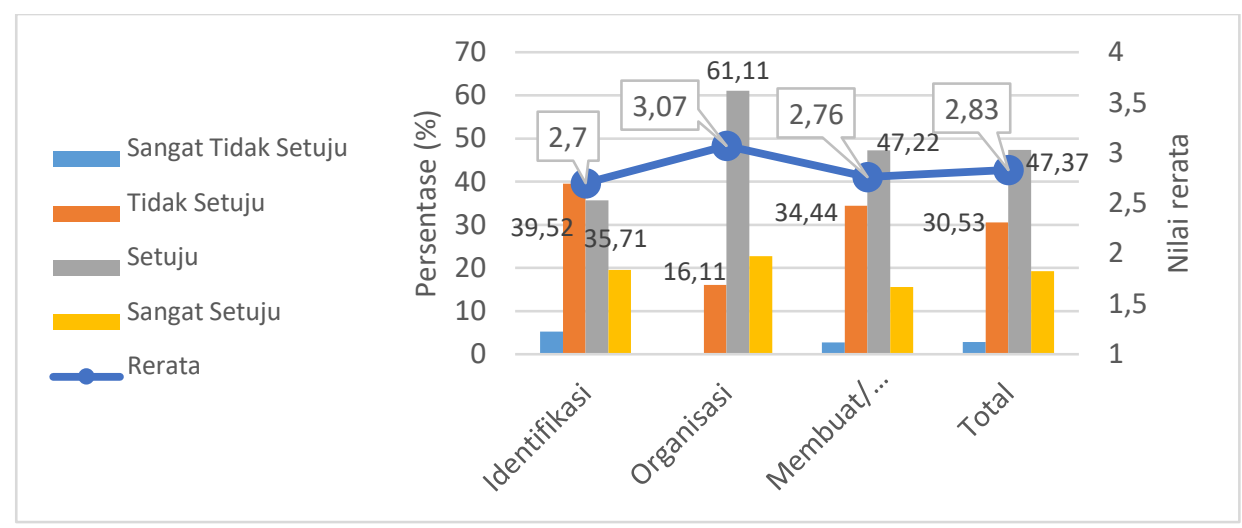

Gambar 3. Sebaran persentase dan rerata data Sesudah diklat

Dari skor rerata ketiga aspek yaitu kemampuan Identifikasi (2,70), kemampuan Organisasi $(3,07)$ dan kemampuan Membuat/menciptakan $(2,76)$ bernilai di atas 2,52 yang berarti tergolong kategori "Baik", sehingga secara total ketiga aspek dengan skor 2,83 termasuk kategori "Baik". Jadi, kondisi Sesudah diklat menunjukkan bahwa secara rerata kemampuan literasi informasi peserta diklat setelah pembelajaran mata diklat inti termasuk kategori "Baik".

Analisis terhadap tiga aspek kemampuan literasi informasi diuraikan sebagai berikut.

\section{a. Aspek Kemampuan Identifikasi}

Data aspek kemampuan Identifikasi pada Gambar 4 di bawah menunjukkan skor pada hampir seluruh indikator (Item-1 s.d Item-6 kecuali Item-7) bernilai di bawah 2,52. Kemampuan peserta diklat dalam menentukan topik KTI secara mandiri dan menggunakan trik penelusuran informasi online tergolong yang paling rendah di antara indikator kemampuan lainnya. Sedangkan item-7 yaitu terkait penggunaan sumber informasi noncetak/online, berada pada kondisi relatif baik. Secara umum hal ini berarti tingkat literasi informasi peserta aspek kemampuan Identifikasi kondisi Sebelum diklat berada pada kategori rendah. 


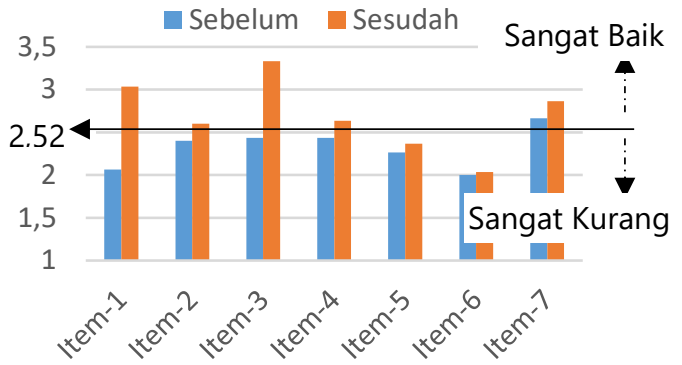

Gambar 4. Nilai rerata aspek kemampuan Identifikasi Sebelum dan Sesudah diklat

Pada kondisi Sesudah, skor pada seluruh indikator (Item-1 s.d Item-7) mengalami peneningkatan dibandingkan kondisi Sebelum. Peningkatan tersebut berada pada kategori "Baik" dan/atau "Sangat Baik" (skor $\geq 2,52$ ) terjadi pada indikatorindikator: (1) menentukan topik KTI secara mandiri; (2) memahami sasaran $\mathrm{KTI}$; (3) memahami kaidah dan format

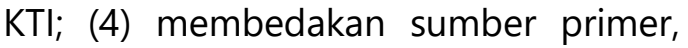
sekunder dan tersier; serta (7) penggunaan sumber informasi online dari internet/intranet.

Data tersebut menunjukkan kemampuan peserta yang meningkat paling dominan terjadi pada indikator (1) dan (3). Artinya, setelah selesai menerima materi-materi DTS Publikasi Ilmiah, peserta mendapatkan peningkatan kemampuan paling dominan dalam penentuan topik KTI secara mandiri dan pemahaman terhadap kaidah dan format penulisan KTI.

Secara keseluruhan perbandingan aspek kemampuan Identifikasi pada kedua kondisi Sebelum dan Sesudah ditunjukkan secara visual melalui grafik Box and Whisker Plots atau grafik Box-plot.

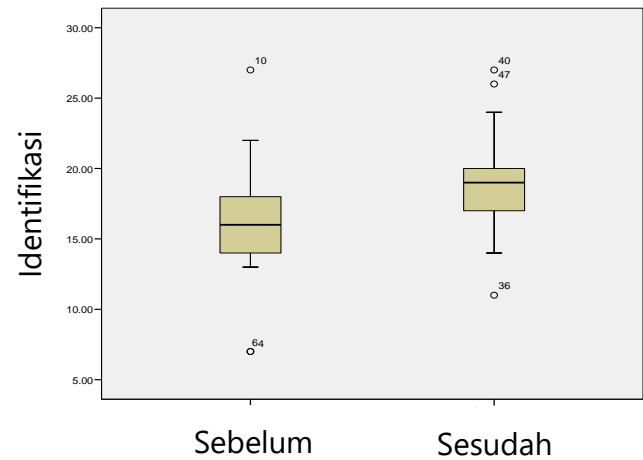

Gambar 5. Hasil box-plot aspek kemampuan Identifikasi

Box-plot pada Gambar 5 menunjukkan median data Sesudah meningkat cukup tinggi dengan simpangan tidak banyak berbeda dibandingkan data Sebelum. Adapun sebarannya cenderung lebih simetris dibandingkan data Sebelum tetapi memiliki tiga outlier. Hal ini memperkuat gambaran bahwa tingkat literasi informasi aspek kemampuan identifikasi kondisi Sesudah diklat relatif lebih baik dibandingkan kondisi Sebelum diklat.

Berdasarkan hal tersebut, dapat dikatakan bahwa pembelajaran mata diklat kelompok inti berpengaruh meningkatkan kemampuan literasi informasi peserta terutama pada indikator-indikator tersebut.

\section{b. Aspek Kemampuan Organisasi}

Dari Gambar 6 di bawah terlihat seluruh indikator kemampuan Organisasi (Item-8 s.d Item-13) pada kondisi Sebelum diklat memiliki skor $\geq$ 2,52 . Hal ini berarti tingkat literasi informasi aspek kemampuan Organisasi Sebelum diklat berada pada kategori "Baik". Begitu juga untuk kondisi Sesudah, skor seluruh indikator/Item bernilai diatas 2,52 dan meningkat dibandingkan kondisi Sebelum diklat. 


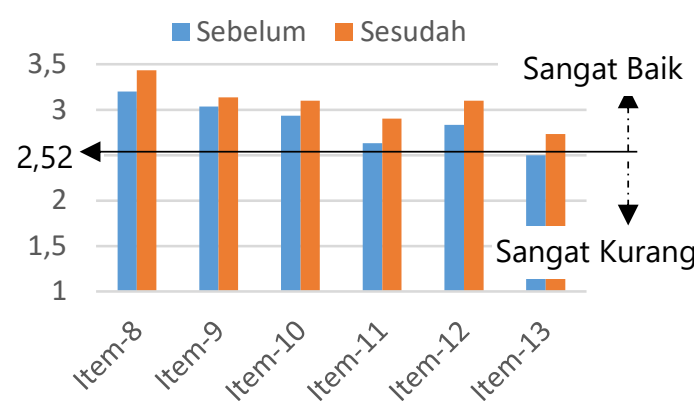

Gambar 6. Nilai rerata aspek kemampuan Organisasi Sebelum dan Sesudah diklat

Indikator-indikator yang mengalami peningkatan adalah: (8) memilih informasi sesuai kebutuhan; (9) membedakan fakta, pendapat dan fiksi; (10) memeriksa informasi akurat dan dapat dipertanggungjawabkan; (11) mengurutkan informasi secara logis; (12) memahami informasi visual; serta (13) mengumpulkan sitasi yang sesuai kebutuhan.

Secara visual melalui grafik boxplot (Gambar 7) di bawah ini terlihat median data Sesudah sedikit meningkat dengan simpangan tidak banyak berbeda dibandingkan data Sebelum.

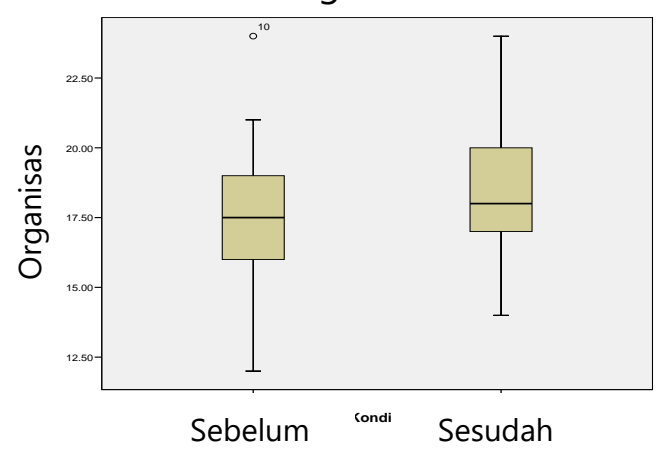

Gambar 7. Hasil boxplot aspek kemampuan Organisasi

Secara sebaran data, kondisi Sesudah cenderung lebih simetris dibandingkan data Sebelum dan tidak memiliki outlier.

Oleh karena itu dapat dikatakan bahwa setelah para peserta diklat mengikuti serangkaian mata diklat kelompok inti, tingkat literasi informasi pada aspek kemampuan Organisasi meningkat menjadi kategori "Baik" dan/atau "Sangat Baik". Data peningkatan pada item-item tersebut secara analitik menunjukkan bahwa peserta diklat merasa memperoleh manfaat dari proses pembelajaran mata diklat inti DTS Publikasi IImiah.

Namun demikian, apakah peningkatan tersebut signifikan atau tidak, selanjutnya akan diperiksa melalui pengujian sebagaimana dijelaskan pada bagian uji signifikansi.

\section{c. Aspek Kemampuan Membuat/ menciptakan}

Pada aspek kemampuan Membuat/ menciptakan seperti tampak Gambar 8 di bawah, skor seluruh indikator kemampuan Membuat/ menciptakan (Item-14 s.d Item-19)

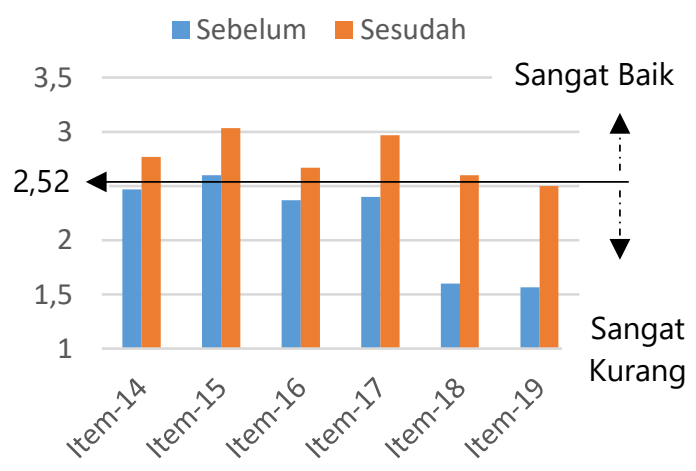

Gambar 8. Nilai rerata aspek kemampuan Membuat/ menciptakan Sebelum dan Sesudah diklat

berada di bawah nilai 2,52. Hal ini menunjukkan bahwa peserta diklat mempersepsikan kemampuan dirinya dalam indikator tersebut termasuk kategori "Kurang" dan/atau "Sangat Kurang". Terutama paling rendah adalah pada indikator kemampuan membuat daftar pustaka dan mengelola 
daftar pustaka menggunakan tool/software manajemen referensi. Sedangkan kategori "Baik" hanya pada Item-15 atau indikator mengemas ulang informasi.

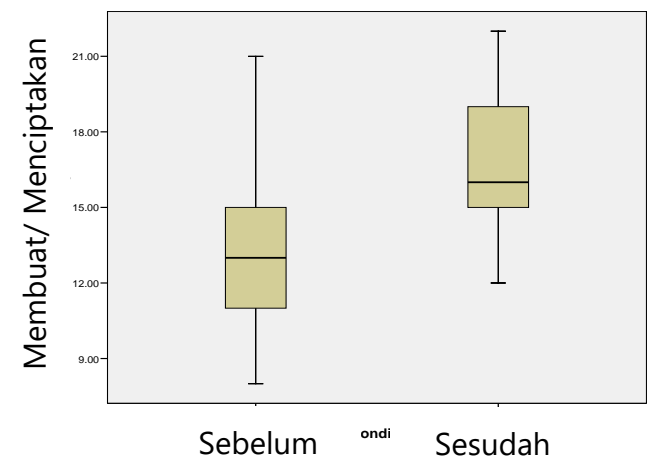

Gambar 9. Hasil boxplot aspek kemampan Membuat/ Menciptakan

Adapun kondisi Sesudah, hampir seluruh indikator pada aspek kemampuan Membuat/ menciptakan berada dalam kategori "Baik" (skor $\geq$ $2,52)$ dan meningkat cukup banyak dibandingkan kondisi Sebelum. Kategori "Baik" tampak pada indikatorindikator: (14) menggunakan pendapat sendiri dalam menyusun $\mathrm{KTI}$ (15) mengemas ulang informasi; (16) mengedit dan merevisi KTI mandiri; (17) membuat kesimpulan dan abstrak; dan (18) membuat daftar pustaka dari informasi yang didapatkan. Untuk indikator (19) membuat daftar pustaka menggunakan tools/sofware manajemen referensi meski meningkat cukup banyak dibandingkan kondisi Sebelum tetapi masih dalam kategori "Kurang" (skor < 2,52).

Box-plot aspek kemampuan Membuat/ menciptakan pada Gambar 9 menunjukkan secara visual bahwa median data Sesudah meningkat cukup banyak dengan simpangan dan kesimetrisan yang lebih baik dibandingkan data Sebelum.
Dengan demikian dapat dikatakan bahwa para peserta diklat juga merasa memperoleh peningkatan kemampuan pada aspek ini setelah mengikuti serangkaian mata diklat DTS Publikasi Ilmiah. Terlihat sebagian besar indikator ketiga aspek kemampuan literasi informasi terjadi perubahan akibat pembelajaran mata diklat. Hal ini berarti bahwa berdasarkan persepsi peserta diklat materi-materi DTS Publikasi Ilmiah bermanfaat dalam meningkatkan literasi informasi aspek kemampuan Membuat/ menciptakan. Namun, tingkat signifikansi perubahan tersebut masih belum diketahui sebelum dilakukan pengujian. Dalam hal ini pengujian signifikansi dilakukan menggunakan uji-t pada tingkat kepercayaan $95 \%$.

\section{Signifikansi Peningkatan Kompetensi Literasi Informasi}

Sebagaimana prosedur dalam uji-t untuk komparasi mean, terlebih dahulu dilakukan uji normalitas untuk mengetahui apakah data Sebelum dan Sesudah berdistribusi/menyebar normal atau tidak. Oleh karena data sample berukuran dibawah 50 maka digunakan uji normalitas Shapiro-Wilk pada tingkat kepercayaan 95\% dan diperoleh hasil sebagai berikut.

Tabel 5. Hasil uji normalitas Shapiro-Wilk

\begin{tabular}{|c|c|c|c|c|}
\hline \multirow{3}{*}{ Aspek } & \multirow{3}{*}{ Kondisi } & \multicolumn{3}{|c|}{ Shapiro-Wilk } \\
\hline & & Statisti & & \\
\hline & & C & Df & Sig. \\
\hline \multirow{2}{*}{$\begin{array}{l}\text { Identifikas } \\
\text { i }\end{array}$} & Sebelum & ,942 & 30 & , 105 \\
\hline & Sesudah & ,948 & 30 &, 152 \\
\hline \multirow[t]{2}{*}{ Organisasi } & Sebelum & 959 & 30 & ,288 \\
\hline & Sesudah & ,953 & 30 & , 198 \\
\hline \multirow{2}{*}{$\begin{array}{l}\text { Membuat/ } \\
\text { Menciptak } \\
\text { an }\end{array}$} & Sebelum & ,957 & 30 & ,264 \\
\hline & Sesudah & ,947 & 30 & , 139 \\
\hline
\end{tabular}




\begin{tabular}{lllll}
\hline Total & Sebelum & 954 & 30 &, 218
\end{tabular}

Sesudah $\quad 986 \quad 30 \quad 947$

* This is a lower bound of the true significance.

a Lilliefors Significance Correction

Berdasarkan Tabel 5 tersebut, nilai Sig. untuk variabel/aspek kemampuan Identifikasi, kemampuan Organisasi, dan kemampuan Membuat/menciptakan serta secara
Total pada kondisi Sebelum dan Sesudah bernilai $>0,05$. Berarti data tersebut memenuhi distribusi normal, sehingga uji-t dapat dilakukan.

Dengan melakukan uji-t untuk sampel berpasangan (Paired sample ttest) melalui SPSS diperoleh hasil sebagaimana Tabel 6 berikut ini.

Tabel 6. Hasil uji-t untuk komparasi mean Sebelum dan Sesudah

\begin{tabular}{|c|c|c|c|c|c|c|c|c|c|}
\hline & & \multicolumn{5}{|c|}{ Paired Differences } & \multirow[b]{3}{*}{$\mathrm{t}$} & \multirow[b]{3}{*}{ Df } & \multirow[b]{3}{*}{$\begin{array}{l}\text { Sig.(2- } \\
\text { tailed) }\end{array}$} \\
\hline & & \multirow[b]{2}{*}{$\begin{array}{c}\text { Mea } \\
\mathrm{n}\end{array}$} & \multirow[b]{2}{*}{ Std. Dev } & \multirow{2}{*}{$\begin{array}{l}\text { Std. } \\
\text { Error } \\
\text { Mean }\end{array}$} & \multicolumn{2}{|c|}{$\begin{array}{c}95 \% \\
\text { Confidence } \\
\text { Interval of the } \\
\text { Difference }\end{array}$} & & & \\
\hline & & & & & $\begin{array}{c}\text { Lowe } \\
r\end{array}$ & Upper & & & \\
\hline Pair 1 & $\begin{array}{l}\text { Sebelum } \\
\text { Sesudah }\end{array}$ & $-2,60$ & 1,30 &, 24 & $-3,09$ & $-2,11$ & $\begin{array}{r}- \\
10,93\end{array}$ & 29 & ,000 \\
\hline Pair 2 & $\begin{array}{l}\text { Sebelum } \\
\text { - } \\
\text { Sesudah }\end{array}$ & $-1,27$ & 1,48 & ,27 & $-1,82$ &,- 71 & $-4,67$ & 29 & ,000 \\
\hline Pair 3 & $\begin{array}{l}\text { Sebelum } \\
\text { - } \\
\text { Sesudah }\end{array}$ & $-3,53$ & 2,06 &, 38 & $-4,30$ & $-2,76$ & $-9,38$ & 29 & ,000 \\
\hline Total & $\begin{array}{l}\text { Sebelum } \\
\text { - } \\
\text { Sesudah }\end{array}$ & $-7,40$ & 3,51 & ,64 & $-8,71$ & $-6,09$ & 11,52 & 29 &, 000 \\
\hline
\end{tabular}

Berdasarkan Tabel 6, ketiga aspek literasi informasi yaitu kemampuan Identifikasi, kemampuan Organisasi dan kemampuan Membuat/menciptakan memiliki nilai Sig. (2-tailed) $<0,05$. Begitu juga nilai Sig. (2-tailed) secara Total $<0,05$. Hal ini dapat disimpulkan bahwa hipotesis $\mathrm{H}_{0}$ ditolak dan $\mathrm{H}_{1}$ diterima.

Kesimpulan yang sama
diperoleh dengan melihat
perbandingan nilai thitung dan nilai t
tabel pada derajat bebas $/ \mathrm{df}=29$ dan taraf signifikansi $0,05\left(t_{\text {tabel }}=2,045\right)$. Pada aspek literasi informasi tersebut, nilai thitung $=-10,93$. Pada aspek kemampuan Organisasi, $t_{\text {hitung }}=-$ 4,67. Pada aspek kemampuan Membuat/menciptakan, nilai $t_{\text {hitung }}=$ $-9,38$. Secara total nilai $t_{\text {hitung }}=-$ 11,52. Sebagaimana dasar pengambilan keputusan, baik masing-masing variabel/aspek kemampuan literasi informasi tersebut maupun secara total diperoleh informasi $\left|t_{\text {hitung }}\right|>t$ tabel, maka hipotesis $\mathrm{H}_{0}$ ditolak dan $\mathrm{H}_{1}$ diterima.

Jadi, dapat dikatakan bahwa terdapat perbedaan yang signifikan antara kondisi Sebelum dan Sesudah 
diklat pada semua variabel. Pembelajaran mata diklat pada kelompok inti dalam DTS Publikasi Ilmiah menunjukkan pengaruh signifikan dalam meningatkan literasi informasi peserta diklat. Artinya keikutsertaan guru-guru madrasah dalam DTS Publikasi IImiah berdampak pada peningkatan literasi informasi.

Peningkatan literasi informasi tersebut secara simultan akan berpengaruh terhadap kinerja mereka. Sebagaimana Ochanantha (2017) memperkuat hasil penelitian Raharja (2014) dan Sutiyono (2010) yang menyimpulkan bahwa diklat atau pelatihan berbasis kompetensi berpengaruh signfikan terhadap peningkatan kinerja (Octhanantha, Al-Musadieq, \& Mukzam, 2017).

Hasil penelitian ini juga menguatkan penelitian sebelumnya yang dilakukan Yasri terhadap 40 orang peserta Diklat Teknis Fungsional Guru MTs pada Pusdiklat Tenaga Teknis Pendidikan dan Keagamaan. Yasri menyimpulkan bahwa program diklat berdampak baik bagi kinerja guru. Kinerja guru yang menunjukkan kondisi baik setelah mengikuti Diklat Teknis Fungsional Guru MTs yaitu dalam menyusun perencanaan pembelajaran, kegiatan melakukan pembelajaran, penguasaan materi pelajaran, dan pembelajaran yang melibatkan siswa (Yasri, 2019).

Meski penelitian Yasri (2019) dan Octhanantha, Al-Musadieq, \& Mukzam (2017) maupun penelitian ini memiliki fokus berbeda-beda namun secara umum dapat ditarik kesimpulan bahwa program diklat berpengaruh pada peningkatan literasi peserta diklat yaitu keterampilan dalam menerima, mencari, mengelola, membuat dan menyajikan informasi sehingga berdampak pada kinerja yang lebih baik.

\section{PENUTUP}

\section{Simpulan}

Kemampuan literasi informasi seseorang dipengaruhi aktivitasnya dalam proses pembelajaran secara langsung maupun tidak langsung, termasuk dalam pembelajaran diklat. Diklat Teknis Substantif Publikasi IImiah bertujuan secara khusus untuk meningkatkan kompetensi peserta dalam bidang penyusunan karya tulis ilmiah yang dipublikasikan. Selain kompetensi tersebut, berdasarkan penelitian ini kemampuan literasi informasi peserta setelah mengikuti diklat mengalami peningkatan yang signifikan sebagaimana dibuktikan hasil uji-t untuk sampel berpasangan (paired sample t-test) pada tingkat kepercayaan $95 \%$.

Peningkatan tersebut terjadi pada hampir semua indikator dari ketiga aspek kemampuan literasi informasi yang diteliti. Pada aspek kemampuan identifikasi dari kategori "kurang" (skor $=2,32<2,52$ ) saat sebelum diklat kemudian meningkat menjadi kategori "baik" (skor $=2,70$ $>$ 2,52) setelah mengikuti diklat. Aspek kemampuan organisasi berada dalam kategori "baik" dengan skor sebelumnya 2,86 meningkat menjadi 3,07 setelah mengikuti diklat. Aspek kemampuan membuat/menciptakan dari kategori "kurang" dengan skor 2,17 meningkat menjadi kategori 
"baik"dengan skor 2,76 setelah mengikuti diklat. Secara rerata dari ketiga aspek tersebut mengalami peningkatan dari kategori "kurang"dengan skor 2,44 menjadi kategori "baik" dengan skor 2,83 setelah mereka mengikuti diklat.

\section{Rekomendasi}

Untuk menerapkan seluruh komponen/tahapan dalam model
Empowering-8, penelitian dapat dilanjutkan setelah para peserta DTS Publikasi Ilmiah menyelesaikan seluruh produk diklat. Yakni, penelitian tahap Sesudah diklat dilakukan setelah para peserta menyelesaikan kegiatan OJT. Hal ini dilakukan untuk memperoleh hasil yang menyeluruh terhadap kecakapan literasi informasi menggunakan model Empowering-8.

\section{DAFTAR PUSTAKA}

Fajarwati, Y. (2012). Pengaruh Kemampuan Literasi Informasi Terhadap Prestasi Belajar Siswa SMAN 1 Depok. Depok: Fakultas Ilmu Pengetahuan Budaya Universitas Indonesia. Diambil kembali dari http://lib.ui.ac.id/file?file=digital/20297394-S1886Yunitha\%20Fajarwati.pdf

Fauziah, N. (2015). Upaya Guru dalam Pengembangan Literasi Informasi Siswa pada Mata Pelajaran PAl. Jakarta. Diambil kembali dari http://repository.uinjkt.ac.id/dspace/bitstream/123456789/29826/1/NUR\%20FAUZIAH \%20-\%20FITK.pdf

Jayanthi, Y. D., \& Cahyana, A. (2014). Pengaruh Hasil Pelatihan terhadap Kinerja Karyawan di Balai Pelatihan Manajerial PT KAI Bandung. Jurnal Pendidikan Luar Sekolah, 10(2). Diambil kembali dari https://ejournal.upi.edu/index.php/pls/article/view/5410/3706

Kompasiana. (2018, Desember 16). Diambil kembali dari Kompasiana: https://www.kompasiana.com/frncscnvt/5c1542ec677ffb3b533d6105/pisa-dan-literasiindonesia

Kusunarningsih, S. (2018). Hubungan antara Kompetensi Literasi Informasi dengan Kemampuan Menulis dan Prestasi Belajar Mahasiswa Unviersitas Airlangga. Diambil kembali dari http://repository.unair.ac.id/74754/3/JURNAL_Fis.IIP.34\%2018\%20Kus\%20h.pdf

Latifah, E. E., \& Husna, J. (2016). Kemampuan Literasi Informasi Siswa Sekolah Menengah Atas Kolese Loyola Semarang Ditinjau dari Prestasi Belajar. Jurnal Ilmu Perpustakaan, 5(3). Diambil kembali dari https://ejournal3.undip.ac.id/index.php/jip/article/view/15241

Muhajang, T. \& Pangestika, M. D. (2018). Pengaruh Literasi Informasi terhadap Efektivitas Belajar Siswa. Pedagonal Jurnal Ilmiah Pendidikan, 2(2)

Marwan, A. (2017). Membangun Gerakan Literasi. Dipetik September 7, 2019, dari http://harian.analisadaily.com/opini/news/membangungerakanliterasi/339316/2017/04/11 
Mirazita, Y., \& Rohmiyati, Y. (2015, April). Studi Literasi Informasi Mahasiswa Ko-Asisten Fakultas Kedokteran Universitas Diponegoro Menggunakan The Empowering Eight Model. Jurnal Ilmu Perpustakaan, 4(2).15-22 Diambil kembali dari https://journal.unpak.ac.id/index.php/pedagonal/article/view/849

Octhanantha, A., Al-Musadieq, M., \& Mukzam, M. D. (2017). Pengaruh Hasil Pelatihan Berbasis Kompetensi Terhadap Kinerja: Studi pada Karyawan Bagian Frontlier PT Bank Mandiri (Persero) Tbk. Area Tangerang Bintaro. Jurnal Administrasi Bisnis, 51(2). Diambil kembali dari https://media.neliti.com/media/publications/189973-ID-pengaruh-hasilpelatihan-berbasis-kompet.pdf

Pattah, S. H. (2014). Literasi informasi: peningkatan kompetensi informasi dalam proses pembelajaran. Jurnal Ilmu Perpustakaan \& Kearsipan Khizanah Al- Hikmah, Vol. 2 No. 2, hlm. 117-128. doi: https://doi.org/10.1210/endo-104-1-101

Pellini, A. (2016, Desember 18). Diambil kembali dari TheJakartaPost.com: https://www.thejakartapost.com/academia/2016/12/18/indonesias-pisa-results-showneed-to-use-education-resources-more-efficiently.html

Permata Ganggi, R. I. (2017). Pendidikan Pemakai di Perpustakaan sebagai Upaya Pembentukan Pemustaka yang Literasi Informasi. Khizanah al-Hikmah: Jurnal Ilmu Perpustakaan, Informasi dan Kearsipan, 5(1), 121-128. doi:https://doi.org/10.24252/kah.v5i1a11

Pusdiklat Tenaga Teknis Pendidikan dan Keagamaan. (2018). Dokumen II Kurikulum Diklat Teknis Substantif Pendidikan. Jakarta: Pusdiklat Tenaga Teknis Pendidikan dan Keagamaan.

Sidharta, J. (2017, Mei 21). Diambil kembali dari Youth Corps Indonesia: https://www.youthcorpsindonesia.org/l/peringkat-pendidikan-indonesia-di-dunia/

Solihat, S. U., Johan, R. C., \& Rosinar, E. (2014). Kontribusi Literasi Informasi Mahasiswa terhadap Proses Penulisan Karya IImiah. EDULIBINFO: Jurnal of Library and Information Science, 1(1), 43-52. Diambil kembali dari https://ejournal.upi.edu/index.php/edulibinfo/article/view/8867/5504

Sudarsono, S. (2011). Kontribusi Masa Kerja, Pendidikan dan Pelatihan, dan Motivasi Kerja Terhadap Kinerja Guru Madrasah Ibtidaiyah Negeri di Kabupaten Jembrana. Jurnal Pendidikan Dasar Ganesha, 1(1). Diambil kembali dari https://www.neliti.com/id/publications/118945/kontribusi-masa-kerja-pendidikandan-pelatihan-diklat-dan-motivasi-kerja-terhada\#cite

Suntoro. (2019). Literasi Informasi Guru Pendidikan Agama Buddha dan Implikasinya dalam Pembelajaran. REFLEKSI EDUKATIKA: Jurnal Ilmiah Kependidikan, 9(2), 183-191. Diambil kembali dari https://jurnal.umk.ac.id/index.php/RE/article/view/3104/1732

Wahyuningsih, D. H. (2012). Evaluasi Program Pelatihan Pengolahan Hasil Pertanian di Balai Latihan Kerja Kabupaten Sukoharjo Tahun 2011. Fakultas Teknik Universitas Negeri Yogyakarta.

Diambil kembali dari 
https://eprints.uny.ac.id/26142/1/Dewi\%20Hermawati\%20Wahyuningsih\%20\%2007511241011.pdf

Wijetunge, P., \& Alahakoon, U. (2005). Empowering-8: The Information Literacy Model Developed in Sri Langka to Underpin Changeing Education Paradigms of Sri Langka. Diambil kembali dari http.www.cmb.ac.lk/academic/institutes/nilis/reports/InformationLiteracy.pdf

Yasri. (2019). Dampak Program Diklat bagi Guru MTs Aspek Pembelajaran. Andragogi: Jurnal Diklat Teknis Pendidikan dan Keagamaan, 7(1), 97-112. doi:https://doi.org/10.36052/andragogi.v7i1.69 